\title{
Supercritical Fluid Chromatography as a Technique to Fractionate High-Valued Compounds from Lipids
}

\author{
Fernando Montañés * and Stephen Tallon
}

Integrated Bioactive Technologies, Industrial Research Limited, 69 Gracefield Road, Lower Hutt 5040, New Zealand; Stephen.Tallon@callaghaninnovation.govt.nz

* Correspondence: Fernando.Montanes@callaghaninnovation.govt.nz; Tel.: +64-4-931-3342; Fax: +64-4-566-6004

Received: 2 February 2018; Accepted: 13 July 2018; Published: 27 July 2018

\begin{abstract}
Natural products are in high demand these days due to rising awareness among consumers. Healthy diets, especially those in emerging markets, growth in populations with nutritional deficiencies, and supporting government regulations provide high growth opportunities for these compounds. However, extraction of high-valued compounds from natural sources is not an easy task. Natural products are complex matrices, with relevant compounds present in small amounts and often mixed with other compounds of similar structures. Most of the applications are related to the pharmaceutical sector, but interest in food and natural products is growing fast. Lipid and carbohydrate extracts are examples of starting materials employed to purify these relevant compounds. At the same time supercritical fluid chromatography (SFC) is an emerging technique for preparative separation due to (1) use of supercritical fluids, commonly carbon dioxide, giving a large reduction in use of organic solvents; and (2) new hardware has been made commercially available recently that makes SFC a viable option. SFC fulfills high demands with respect to selectivity, versatility and sensibility. Fractionation or purification by SFC of high-valued compounds from natural sources is an interesting option, the relevance of which will increase in the future. This paper is a survey of trends and applications of SFC in the field of natural products purification.
\end{abstract}

Keywords: SFC; natural product; omega 3; phospholipid; purification; carbohydrate

\section{Introduction}

\subsection{Natural Products}

Global sales of healthy food products are estimated to have reached $\$ 1$ trillion by 2017 according to Euromonitor [1]. Consumers are using food and dietary supplements as a tool to manage their health. It doesn't seem to be a temporary fashion. A 2015 survey suggests that consumers have shifted their mindset and are willing to pay more for healthy products [1]. Some of the compounds that will be reviewed in this paper have an expected compound annual growth rate (CAGR) $>>10 \%$, for example $14.9 \%$ for the omega-3 market and $25.8 \%$ for nuts and seeds, during the period 2016-2022 [2] and 19.1\% during the period 2015-2020 for the phospholipid market [3]. Local and international markets are progressively looking towards natural and organic products versus synthetic [4]. Laws and policies that promote healthy food and limit access to unhealthy food are critical drivers to see increase in consumption of these kind of products. Natural products are not only used in foods, with the ageing population resulting in an increase in the demand of cosmetics and antioxidant products for improving aesthetic appeal. Natural products have provided considerable value to the pharmaceutical industry over the past half century. In particular, the therapeutic areas of infectious diseases and oncology have benefited from numerous drug classes derived from natural product sources [5]. 
Among the functional foods with health claims that are marketed worldwide at present, peptides, polyphenols, carotenoids, polyunsaturated fatty acids or sterols and stanol, just to name a few, are obtained from natural sources. The most common raw materials are plants, marine organisms, including microalgae and seaweeds, but also food- and agri-food related by-products [4]. Obtention of high-valued compounds from natural matrices' needs to reduce energy consumption by using innovative technologies and take advantage of these complex mixtures to produce co-products instead of waste when obtaining the main product.

\subsection{SFC Overview}

As mentioned above, natural matrices are very complex and powerful separation tools that are required to obtain the final product. In order to be fully utilized, the bioactive compounds contained in those matrices should be selectively extracted, minimizing the co-extraction of unwanted materials while looking for high extraction efficiency, minimal degradation of the active compound, and minimal cost and environmental impact. To achieve these requirements, advanced environmentally clean extraction techniques using green solvents are needed. Techniques based on the use of compressed fluids clearly fall within that category. Pressurized liquid extraction (PLE), supercritical fluid extraction (SFE) or gas-expanded liquid (GXLs) extraction are the most-widely employed. These techniques are characterized by the possibility of using appropriate green solvents, but keeping in mind the highest possible reduction in the total volume needed. The properties that an ideal green solvent should possess include: (1) low toxicity to humans and other organisms; (2) easily biodegradable in the environment without adverse effects; (3) naturally occurring; (4) produced from renewable sources; (5) produced as a by-product; (6) low vapor pressure; (7) no need of a traditional evaporation step after extraction. SFC technology can fit in this category. SFC is an analytical technique that employs a supercritical fluid as mobile phase (carbon dioxide is the most common one) and takes advantage of the ability to adjust its solvating power according to the conditions required [6]. Although SFC has some major potential advantages such as a high-resolution and high-throughput, its development and use has not been as intensive as GC and HPLC.

Although it has been used since early 1960, it has been the last 20 years that this technology has taken off when specific instrumentation has been developed. SFC reduces solvent consumption and disposal, and also energy in fractionation and evaporation processes. These systems are well suited to different purposes, and are capable to deliver efficiency and sensitivity rivaling that offered by high pressure liquid chromatography (HPLC). The novel backpressure regulator design, the high pressure limits, and the reduced void volumes make these instruments fully compatible with small diameter particles $(<2 \mu \mathrm{m})$ and core-shell columns. More detailed explanation can be found elsewhere. SFC meets strict law requirements about environmental protection and has gained a reputation as a "green technique".

Instrumentation for SFC can be obtained commercially or by adapting systems used for either liquid chromatography (LC) or gas chromatography (GC). Most detectors used in GC and HPLC can be used with SFC, but mainly flame ionization detector (FID) and ultra-violet (UV) are used. Coupled detectors employed are Mass spectrometry (MS) and Fourier-transform infrared spectroscopy (FTIR). SFC is faster than LC because supercritical fluids have low viscosities and less pressure drop across the column. SFC advantages compared to GC include that no derivatization is needed, and it is possible to analyze thermally labile compounds and solutes of higher molecular weight. Open tubular and packed columns are used. Currently, all companies manufacturing SFC packed columns are offering a similar catalogue of products. Due to the finite body of knowledge of the interaction between analytes and SFC systems, it is difficult to select the most appropriate stationary phase a-priori. To avoid testing several stationary phases for each experiment West and Lesellier developed a method to classify stationary phases based on the use of the linear solvation energy relationship (LSER) [7-14].

SFC systems generally consist of gas supply, pump(s), sample injector, oven, column(s), detector, back pressure regulator/restrictor and computer to control the entire process. A system used by 
authors is presented in Figure 1. The built in-house setup and a UV-vis detector were employed for sample detection and fractionation.

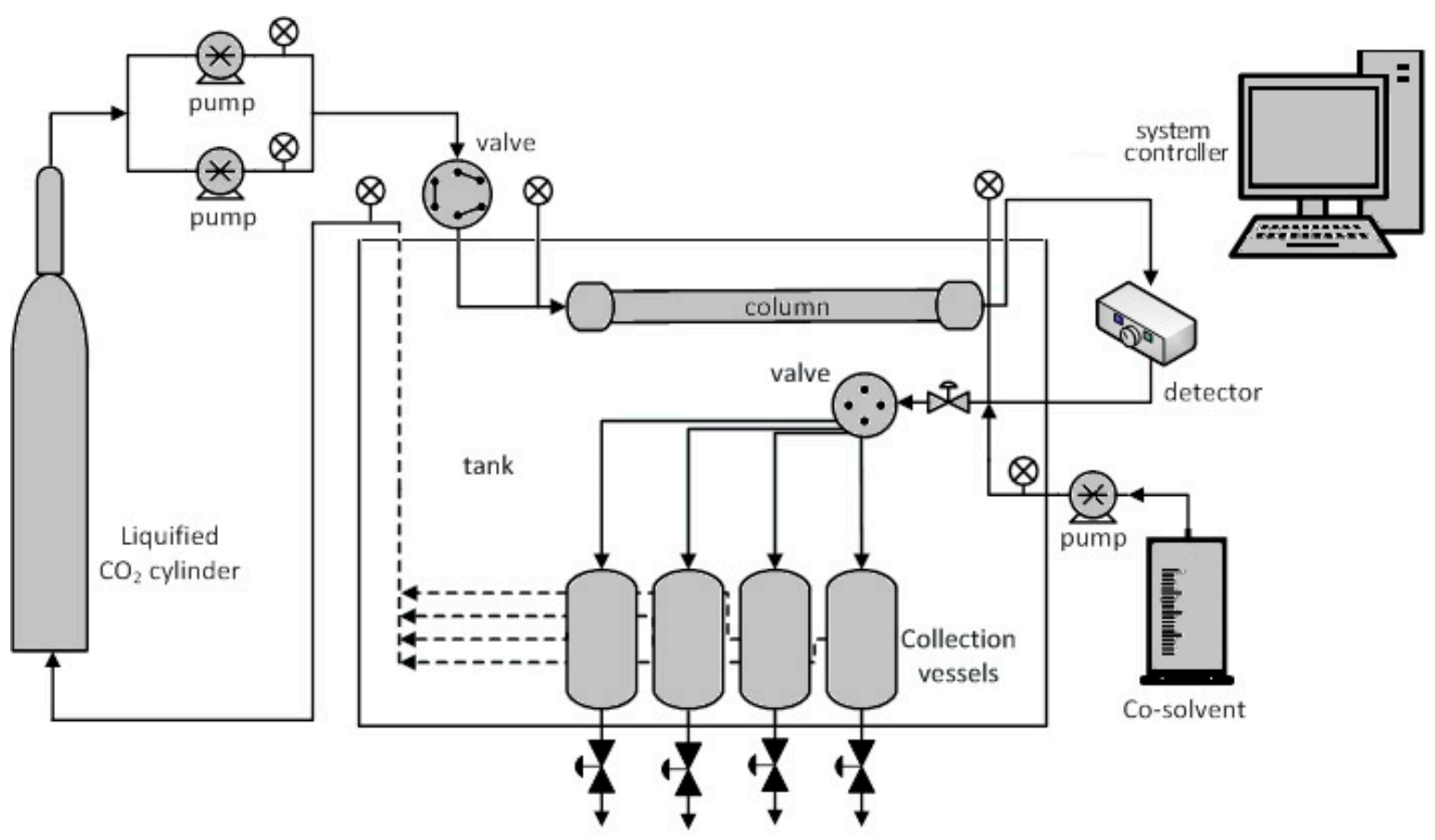

Figure 1. Schematic diagram of a SFC experimental apparatus.

SFC has been the single most important technique used in the pharmaceutical industry for the detection, separation, and purification of chiral molecules. It has been a suitable alternative to HPLC in chiral separations because of its high speed, shorter analysis time, limited environmental impact, and higher efficiency. SFC has met the chromatography needs of the pharmaceutical industry by providing efficient and selective testing capabilities on the analytical, semi-preparative, and preparative scale. SFC now occupies a niche in the discovery and development of a wide variety of drugs such as antibiotics, steroids, non-steroidal anti-inflammatory drugs, barbiturates, and prostaglandins [15]. SFC applications in the area of food analysis have traditionally been focused on non-polar mixtures, like fats and oils, free fatty acids, oil-soluble vitamins, tocopherols, and sterols, due to the high solubility of these analytes in supercritical $\mathrm{CO}_{2}$. Innovations in SFC mobile phases have opened up much more polar application areas to SFC. These include peptides, phospholipids, polyphenols, natural antioxidants, small carbohydrates, and alkaloids, to name but a few. Several studies have shown the capacity of SFC for analysis of more polar compounds, such as amino acids or carbohydrates, by using mobile phases modified with a certain proportion of water [16]. Moreover, the possibility of using columns with different functionality and employing the same mobile phase, in conjunction with the feasibility of serially coupling columns, has made it possible to enlarge the range of compounds that can be separated in the same run. The analysis of complex mixtures has been accomplished by using 2D SFC or coupling SFC to RP-HPLC, but increasingly the SFC-MS combination is now being chosen, providing very good levels of sensitivity. On a preparative scale, SFC is a suitable alternative to liquid chromatography, with sound results in the isolation of food components with a high bioactive value, such as polyunsaturated fatty acids or tocopherols. It is also logical to couple SFC with supercritical fluid extraction (SFE) for the raw biomass, since the classes of compounds to be handled are common, as are aspects of the technologies and expertise [17]. 


\section{Current State}

SFC is a mature technique for analysis and separations of compounds from natural matrices. It is well demonstrated with large amount of published literature in this field [17,18]. In this current paper the focus is put on SFC applications for fractionation and enrichment of certain high-valued compounds with scale up possibilities.

\subsection{Lipids}

Lipids play a vital role in biological processes such as energy storage, morphogenesis, protein trafficking, cellular signalling or as structural components of cell membranes [19]. Since SFC beginnings, lipids have been one of the main areas of research, as is described elsewhere. Lipid analysis and profiling have been very useful in a wide range of fields, such as food, cosmetics, and pharmaceuticals but there is still limited research in the area of purification/fractionation. The greatest and most successful effort has been focused on obtaining very highly concentrated fatty acids or single fatty acids. This application is the only one known to have reached industrial scale, with two companies (KD-Pharma, Bexbach, Germany and Bioibérica, Barcelon, Spain) offering eicosapentaenoic acid (EPA) and docosahexaenoic acid (DHA) with purities $>99 \%$, respectively, using SFC.

\subsubsection{Polyunsaturated Fatty Acids (PUFA)}

PUFAs are very important compounds in human health, especially $\omega-3$ PUFA. This fact has spurred research in the area to produce highly enriched mixtures, primarily fish derived fatty acids including EPA and DHA, and also vegetable fatty acids including $\alpha$-linolenic acid (ALA), which are considered high value. Due to health concerns about fisheries, seasonality and overexploitation, there has been research and development into new raw materials, such as marine micro-, macro-algae and transgenic plants as potential sustainable sources of EPA and DHA [20,21] as alternatives to fish and krill. The main drawback to the use of algae is the high cost to produce biomass, because the desired fatty acids are mainly membrane bound; and the cost of production by fermentation. In the other side, consumers are still very cautious to acquire products made of transgenic plants and regulations in many countries are against genetically modified organisms. ALA, EPA and DHA from non-fish origin provide desirable labels such as vegetarian, kosher or organic [22]. Most of the EPA/DHA oil is used for dietary supplements, followed by pet foods, food and beverage, infant formula [22]. Nutraceutical market requires $\omega-3$ concentrates with purities $\geq 60 \%$ and pharmaceutical market $\geq 95 \%$.

Lots of health claims can be found, but the only ones approved for independent bodies such as EFSA (European Food Safety Agency) are the following ones:

- DHA and EPA: contribute to normal function of the heart, to the maintenance of normal blood pressure and triglycerides levels.

- DHA: contributes to maintenance of normal brain function, to the normal brain and eyes development of the foetus and breastfed infants

- $\quad$ ALA: contributes to brain development.

In general, an oil or lipid mixture that contains PUFA to be concentrated by SFC must be first converted to ethyl/methyl esters or free fatty acids [23]. As mentioned above, production of $\omega-3$ concentrates has been a very popular field not only for separation but also for enrichment since 1990s. Table 1 summarizes efforts done in this subject. 
Table 1. $w-3$ enrichment summary using SFC technology

\begin{tabular}{|c|c|c|c|c|c|c|c|c|c|}
\hline \multirow{2}{*}{ Reference } & \multirow{2}{*}{ Feed Material } & \multirow{2}{*}{ Ester Form } & \multirow{2}{*}{ Stationary Phase } & \multirow{2}{*}{ Mobile Phase } & \multirow{2}{*}{$\begin{array}{c}\text { Experimental } \\
\text { Conditions }(\mathrm{P} / \mathrm{T})\end{array}$} & \multicolumn{2}{|c|}{ Feed Concentration (\%) } & \multicolumn{2}{|c|}{ Final Concentration (\%) } \\
\hline & & & & & & EPA & DHA & EPA & DHA \\
\hline [24] & Sardine oil & Methylated & $\begin{array}{l}\text { Silica gel coated with } \\
\text { silver nitrate }\end{array}$ & $\mathrm{CO}_{2}$ & $\begin{array}{l}\text { 80-200 bar } \\
313 \mathrm{~K}\end{array}$ & 12 & 13 & 93 & 92 \\
\hline$[25]^{*}$ & Marine oil & Ethylated & $\begin{array}{l}\text { Reverse phase octadecyl } \\
\text { silica gel }\end{array}$ & $\begin{array}{l}\text { Acetonitrile/water } \\
\text { or methanol/water }\end{array}$ & $\begin{array}{l}200 \mathrm{bar} \\
323 \mathrm{~K}\end{array}$ & 50 & 30 & 95 & 90 \\
\hline [26] & Tuna oil & Ethylated & Octadecyl silane & $\mathrm{CO}_{2}$ & $\begin{array}{c}145 \mathrm{bar} \\
338 \mathrm{~K}\end{array}$ & NA & NA & 50 & 90 \\
\hline [27] & Menhaden oil & Ethylated & $\begin{array}{c}\text { 0.375" ball bearings } 304 \text { SS or } \\
0.16^{\prime \prime} \text { Propak } 316 \text { SS }\end{array}$ & $\mathrm{CO}_{2}$ & $\begin{array}{c}150-170 \text { bar } \\
313-373 \mathrm{~K}\end{array}$ & NA & NA & NA & NA \\
\hline [28] & Fish oil & Ethylated & $\begin{array}{l}220 \mathrm{~kg} \text { porous silicon dioxide } \\
\text { impregnated with } \\
\text { (3-aminopropyl)-triethoxysilane }\end{array}$ & $\mathrm{CO}_{2}$ & $\begin{array}{l}100-150 \text { bar } \\
313-333 \mathrm{~K}\end{array}$ & 50 & --- & 95 & --- \\
\hline [29] & Fish oil & Ethylated & Silica gel & $\mathrm{CO}_{2}$ & $\begin{array}{c}150-220 \text { bar } \\
343-353 \mathrm{~K}\end{array}$ & 68 & --- & 93 & --- \\
\hline$[30]^{* *}$ & Fish oil & Ethylated & Amino-bonded silica & $\mathrm{CO}_{2}$ & $\begin{array}{c}170 \text { bar } \\
310 \mathrm{~K}\end{array}$ & NA & NA & NA & NA \\
\hline [31] & Algae oil & Ethylated & Silica-PFP *** & $\mathrm{CO}_{2}$ & $\begin{array}{c}170 \mathrm{bar} \\
333 \mathrm{~K}\end{array}$ & 16 & 0.7 & 86 & 72 \\
\hline [31] & Fish oil & Ethylated & Silica-PFP *** & $\mathrm{CO}_{2}$ & $\begin{array}{c}170 \mathrm{bar} \\
333 \mathrm{~K}\end{array}$ & 18 & 9.1 & 94 & 83 \\
\hline
\end{tabular}

P: pressure; T: temperature. ${ }^{*}$ SFC + counter-current bed chromatography. ${ }^{* *}$ Results in this study were scaled up to an industrial plant (KD-Pharma in Spain). NA: not available.

*** PFP: pentafluorophenyl. 
Montanes et al. [31] carried out some work studying and optimizing several experimental parameters using pure $\mathrm{CO}_{2}$ as a mobile phase in a one step process at semi-preparative scale. Parameters considered were: (1) chromatographic parameters; (2) sample loading; (3) mobile phase flow rates; (4) particle size for same stationary phase (unmodified silica); (5) different silica columns bonded with different chemical groups; (6) $\omega$-3 feed material; and, (7) In-house or commercially available packed columns. Good experimental conditions were established at 170 bar, $333 \mathrm{~K}$ and flow rate ranging from 3.3 to $8.3 \mathrm{~g} \mathrm{CO}_{2} / \mathrm{min}$ in a $250 \mathrm{~mm} \times 20 \mathrm{~mm}$ column. For the selected operating conditions, depending on feed material, a high level of EPA and DHA enrichment was achieved [31] (see Table 1), and $>>99 \%$ enrichment of combined $\omega-3$ 's. For some specific conditions arachidonic and stearidonic acids were enriched $>80 \%$. From data unpublished yet, when the feed material oil has a higher content on DHA, the authors obtained DHA with purities $>95 \%$. DHA was more difficult to purify not just because of lower quantities in the starting material, but because it usually elutes very close to docosapentaenoic acid (DPA), another $\omega-3$ fatty acid. Regarding stationary phases employed, no significant differences where found between different columns using $5 \mu \mathrm{m}$ particle size. Columns with larger particle size gave lower purity, although still considerable enrichment (EPA $>80 \%$ ) using $15 \mu \mathrm{m}$ particle size. The provisional work using a pilot scale facility using a $10 \mathrm{~L}$ unmodified silica column and 63-200 $\mu \mathrm{m}$ particle size, as the stationary phase was carried out. Although $\omega-3$ 's were enriched up to $70 \%$ using similar working conditions to the smaller scale trials, we were not able to separate substantially EPA from DHA. The main problems related with upscaling are the increased costs of using expensive special coated packings, and also pressure drop across the column particularly for smaller particle size [23].

Montanes et al. [32] also address fractionation of uncommon PUFAs, such as non-methylene interrupted (NMI) PUFAs and PUFAs containing triple bonds, from different oil sources. Target fatty acids to enrich were juniperonic acid (JA) for NMI, and ximenynic acid (XA) for PUFAs containg triple bonds. JA fractionation was attempted under two fatty acid forms: fatty acid ethyl esters (FAEE) and free fatty acids (FFA). Beneficial properties reported for JA and XA are anti-inflammatory [33], anti-proliferative [34] and cholesterol lowering [35,36] activities, enhancement of memory [37-39], modulation of immune response [40], or supression of hypertension [41], amongst others. The authors used the same working conditions described above ( 170 bar and $333 \mathrm{~K}$ ) and stationary phases, with similar flow rates (adjusted for each specific sample and stationary phase). For JA FFA, ethanol as co-solvent was used and pressures set up to 300 bar. For XA enrichment $>95 \%$ (best fractionations up to $99.5 \%$ purity) was achieved for particle size $5 \mu \mathrm{m}$ whereas purities $>90 \%$ for particle size $\leq 15 \mu \mathrm{m}$. For JA, FAEE fractionation purities $>80 \%$ were obtained for $5 \mu \mathrm{m}$ particle size unmodified silica and amino phenyl stationary phases. For FFA fractionation purities $>80 \%$ were obtained for both $5 \mu \mathrm{m}$ particle size stationary phases, with the addition of ethanol as a co-solvent and increase of working pressure to 300 bar.

Taylor et al. [42] used SFC coupled with SFE to purify free sterols and phytosterol esters from maize bran at preparative scale. Free sterols were enriched four times and phytosterol esters ten times. Osseo et al. [43] used SFC to purify used frying oils. At 345 bar and $327 \mathrm{~K}$ using $\mathrm{CO}_{2}$ they were able to concentrate up to $52 \%$ of triglycerides with $97 \%$ recovery. Choo et al. [44] successfully achieved separation of triglycerides, diglycerides, free fatty acids, carotenoids, tocopherol, and tocotrienols from crude palm oil using SFC with a combination of a C18 and a silica gel column.

\subsubsection{Phospholipids}

Phospholipids (PPL) are the most important class of polar lipids as they are structural components of living cell membranes and play an important role in enzyme activation, making them important in nutrition. They are commonly used as emulsifying additives, dispersants, wetting and refatting agents, emollients, stabilizers, liposome-formers, adhesion improvers, etc., with many applications in the food, cosmetic, pharmaceutical, paint, dyes and textile industries. PPLs consist of a glycerol backbone on which 2 fatty acids occupy the first and second positions, and a phosphorous containing 
moiety is attached to the third position. The phosphate moiety is linked to an alcohol containing an amine group (phosphatidylethanolamine (PE) phosphatidylcholine (PC), phosphatidylserine (PS)) or a carbohydrate group (phosphatidylinositol (PI)). Variations include lysophospholipids (e.g., lyso-PI), ether phospholipids in which one of the fatty acids is replaced by a fatty alcohol e.g., PS-plasmalogen. Alternatively, the phosphate group is esterified to sphingosine (sphingophospholipids), with one fatty acid attached to the amine group (sphingomyelin (SM)). They can also be sources or carriers of desirable compounds including polyunsaturated fatty acids and choline.

Analytical techniques traditionally used for phospholipid analysis are thin layer chromatography (TLC), HPLC, GC and NMR, and are summarised in a number of reviews [45]. SFC to fractionate PPLs has been only attempted at analytical scale using $\mathrm{CO}_{2}$ as a mobile phase and co-solvent and additives such as ethanol, methanol, water, triethylamine, isopropylamine, ammonium acetate or trifluoroacetic acid. Basic additives and ionic additives appeared to be more effective than the acidic one since all lipids did not elute with the acidic additive. Using usually bare silica as a stationary phase, with temperatures ranging from 310 to $373 \mathrm{~K}$ and pressure from 52 to 690 bar [46-50]. An example of how PPL production could be approached is shown in Figure 2.

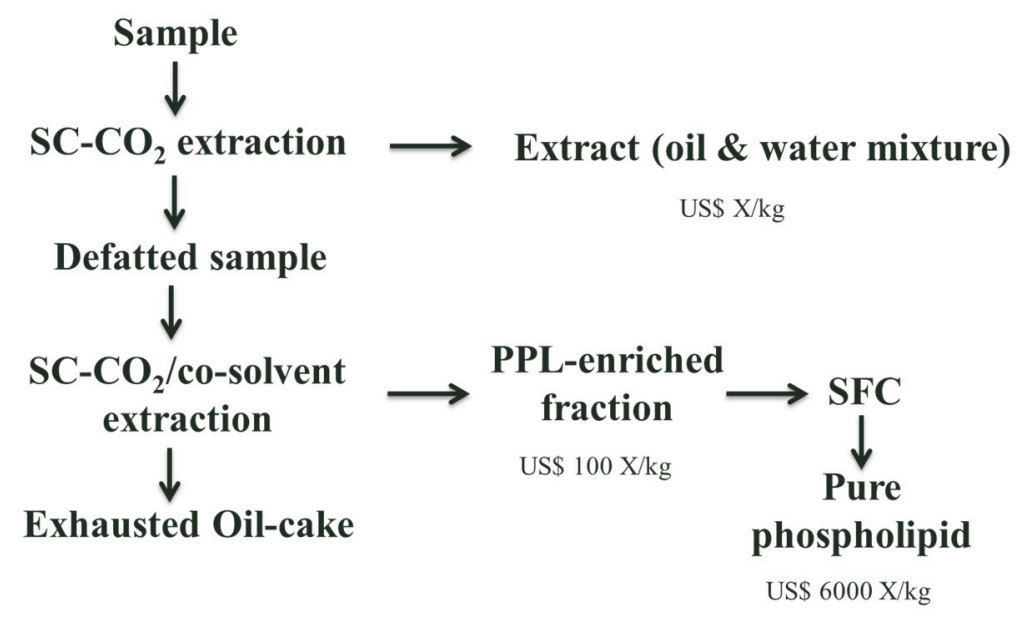

Figure 2. PPL production [51].

The authors have studied fractionation at semi-prepaparative scale of different types of PPLs present in egg yolk samples (data unpublished). $182 \mathrm{mg}$ of egg yolk lecithin (78.9\% total PPLs content) was used to fractionate PPLs (see composition at Table 2). Experimental conditions were 300 bar, $313 \mathrm{~K}$, stationary phase silica bonded with aminophenyl group with $5 \mu \mathrm{m}$ particle size in a $250 \mathrm{~mm} \times 20 \mathrm{~mm}$ column. Mobile phase was $\mathrm{CO}_{2}+$ ethanol employing the following program in three steps: (1) $15 \mathrm{~min}$ flow rate ( $3 \mathrm{~mL} \mathrm{CO}+1 \mathrm{~mL}$ ethanol) $/ \mathrm{min}$; (2) $30 \mathrm{~min}$ flow rate $\mathrm{CO}_{2}$ decreasing to $0 \mathrm{~mL} / \mathrm{min}$ and flow rate ethanol increasing up to $4 \mathrm{~min}$; and finally (3) $15 \mathrm{~min} 3 \mathrm{~mL} / \mathrm{min}$ ethanol. Fractions, analyzed using ${ }^{31} \mathrm{P} \mathrm{NMR}$, that were enriched in PE (diacyl and alkyl-acyl PE) to $>99.5 \%$ of total phospholipids (total phospholipid content was $100 \mathrm{wt} \%$ ) and a fraction enriched in PC up to $>99.5 \%$ of total phospholipids were produced (total phospholipid content of $95.2 \mathrm{wt} \%$ ). Starting materials with PPLs $<10 \%$ were also tested but were not able to be significantly enriched.

The solubility of each single class of PPLs in $\mathrm{CO}_{2}+$ ethanol increases with the ethanol co-solvent concentration at fixed temperature $(\mathrm{T})$ and pressure $(\mathrm{P})$. The solubility is weakly dependent upon pressure and temperature at fixed ethanol concentration. The solubility, at fixed, T, P and ethanol concentration is highly dependent on the PPL head group, and the extent to which the glycerol backbone is esterified to fatty acids (or conjugated to fatty alcohols). The qualitative order of solubility in $\mathrm{CO}_{2}+$ ethanol, from most soluble to least soluble, is: $\mathrm{PC}=\mathrm{AAPC}$ (AA: alkylacyl) $>\mathrm{SM}=\mathrm{DHSM}>$ $\mathrm{PE}=\mathrm{AAPE}=1 \mathrm{LPC} \geq 2 \mathrm{LPC}=\mathrm{CL}$ (cardiolipin) $>1,2 \mathrm{LPE}>\mathrm{PI} \sim \mathrm{PS} \sim$ PA. PI, PS and PA are virtually insoluble in $\mathrm{CO}_{2}+$ ethanol and can thus be separated from more soluble PPLs in an extraction process. 
Table 2. PPLs composition of egg yolk lecithin used in SFC trials.

\begin{tabular}{cc}
\hline PPL & $\%$ \\
\hline PC & 84.3 \\
1 LPC & 0.2 \\
2 LPC & 1.2 \\
PE & 10.5 \\
SM & 2.3 \\
DHSM & 1.1 \\
2 LPE & 0.3 \\
Total PPLs in sample & 78.9 \\
\hline
\end{tabular}

L: lys. SM: sphingomyelin. DH: dihydro.

\subsection{Carbohydrates}

Carbohydrates are one of the three main types of macronutrients. Ubiquitous in nature as polysaccharides, appearing as structural components in biological systems and the most important source of energy for the human body. The body uses carbohydrates for energy for cells, tissues and organs. It stores any extra sugar in liver and muscles for when it is needed.

GC and LC are the most common techniques to fractionate carbohydrates [52]. Only a few studies involving the separation or analysis of carbohydrates by SFC have been reported. Capillary SFC with derivatization of carbohydrates is superior to GC with respect to the molecular mass range that can be used [53]. Packed columns are well adapted for separating non-derivatized mono-, diand trisaccharides, in conjunction with $\mathrm{CO}_{2}$, a modifying solvent and detection by evaporative light scattering (ELSD) [54]. Although SFE has been used to fractionate carbohydrates using modifiers [55-59], only a few studies are available studying fractionation of carbohydrates using SFC. Salvador et al. proposed SFC technology to separate 8 different types of polysaccharides and poliols using silica as a stationary phase [60] and Lefler and Chen [61] separated a mixture of caffeine, fructose, glucose, sucrose and neohesperidine dihydrochalcone, an artificial sweetener. Montanes et al. [62] have studied separation mixtures of derivatized anomeric monosaccharides containing an incorporated chromophore, as a first step to validate SFC as a proper technology for carbohydrates fractionation. The studied mixtures contained, in different ratios, methyl- $\alpha$-D-glucopyranoside and methyl- $\beta$ D-glucopyranoside. Parameters studied were pressure, temperature, sample loaded, stationary phase particle size and mobile phase flow rates $\left(\mathrm{CO}_{2}+\right.$ ethanol). Under optimized SFC experimental conditions the authors were able to recover glucosyde anomers with purities $>98 \%$ and yields $>96 \%$.

\subsection{Other Applications}

As mentioned, SFC technology has been mainly applied to purification of lipids, but there have been efforts to enrich another compounds. Here is a summary of other fractionations. SFC is an alternative separation technique widely used due to its ability to separate cis/trans isomers, especially useful to separate carotenoids. In the analytical studies by Choo et al. [48] the pure fractionation of carotenes was obtained by preparative SFC from crude palm oil. Compounds with antioxidant properties have a great interest for several industries.

SFC technology is useful for vitamin fractionation as an alternative to organic solvent based methods for four important reasons: absence of oxygen, light, $\mathrm{pH}$ variations and high temperatures. Saito et al. [63] isolated $\alpha$ - and $\beta$-tocopherols from wheat germ oil using semi-preparative SFC using two columns (silica $5 \mu \mathrm{m}$ particle size) reaching purities of $85 \%$ and $70 \%$ respectively. Johannsen et al. have studied purification at analytical scale of tocopherols and tocopherol and tocotrienol mixtures using SFC with $\mathrm{CO}_{2}+$ alcohol as a mobile phase $[64,65]$. This group also has been very active to purify tocopherols coupling simulating moving bed (SMB) with SFC.

Antioxidants are closely related with food and diet, but they are used in many industrial applications, namely stabilizers in fuels. The main studies regarding fractionation with SFC are 
from Ramirez et al. [66,67]. The authors were able to fractionate carnosic acid and carnosol (main antioxidant compounds found at rosemary) using $\mathrm{CO}_{2}+10 \%$ ethanol as a modifier and LC-diol $5 \mu \mathrm{m}$ particle size stationary phase in-house packed at semi-preparative scale at 130 bar and $353 \mathrm{~K}$.

Coleman et al. [68] developed at analytical and semi-preparative scale a SFC method to purify davanone from davana oil using $\mathrm{CO}_{2}$ as a mobile phase, and silica-based stationary phases. In optimal conditions davanone fraction was almost $100 \%$ pure from $30 \%$ to $60 \%$ purity starting material.

$\mathrm{Li}$ et al. [69] isolated four different polymethoxyflavones from sweet orange peel (nobiletin,

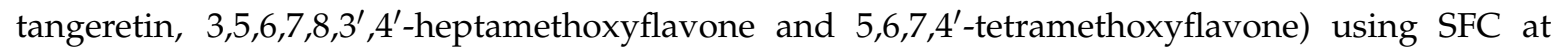
relatively large scale. Also described is preparative scale enrichment of terpenoid-type compounds from Thymus vulgaris essential oil, a valuable source for flavour-based industries [70]. Extracts obtained at 150 bar, $323 \mathrm{~K}$, Kromasil $5 \mu \mathrm{m}$ particle size column and with $3 \%$ ethanol content as a modifier, contained approximately two times more thymol, carvacrol, borneol and $\alpha$-terpineol than feed material.

\section{Future}

SFC is a well established analytical technique, especially for pharmaceutical applications, but not yet a well established preparative fractionation technique. Not many applications are carried out at preparative or larger scale. Pressure drops across the column and the cost of specialized stationary phases seem to be practical and economic issues limiting industrial uptake of SFC. Only $\omega-3$ fractionation has reached maturity and is carried out at production level.

Recent developments towards enabling larger scale use of SFC are exciting and include a number of companies offering dedicated SFC columns. Further research and development designing new stationary phases to widen the scope of target compounds that can be fractionated by SFC is still required. An example could be a very current topic world-wide, cannabinoids. Cannabis contains more than 400 different ingredients, including 66 cannabinoids. The poor availability of the various cannabinoids as pure compounds is an obstacle for the development of cannabinoid based drugs [71] and to produce "standarized" cannabis products.

Most of processes presented in this paper use supercritical $\mathrm{CO}_{2}$ with a co-solvent, making SFC technology costly and complex. This gives an opportunity for other mobile phases working under near-critical conditions such as dimethylether (DME) or propane which have similar advantages as supercritical $\mathrm{CO}_{2}$. Figure 3 shows the polarity of different mobile phases used in near- and supercritical conditions. A much larger range of compounds are separable (low to medium polarity bioactives) at milder working conditions than supercritical $\mathrm{CO}_{2}$ (e.g., separation can be carried out at $10-40$ bar), simplifying construction and reducing cost. DME is an approved solvent for food use in Europe, Australia and New Zealand and is under review for GRAS status in the US. Propane is a permitted extraction solvent in many countries, but is approved only for aerosol food use in the US [27]. The main operational challenge is that they are both flammable.

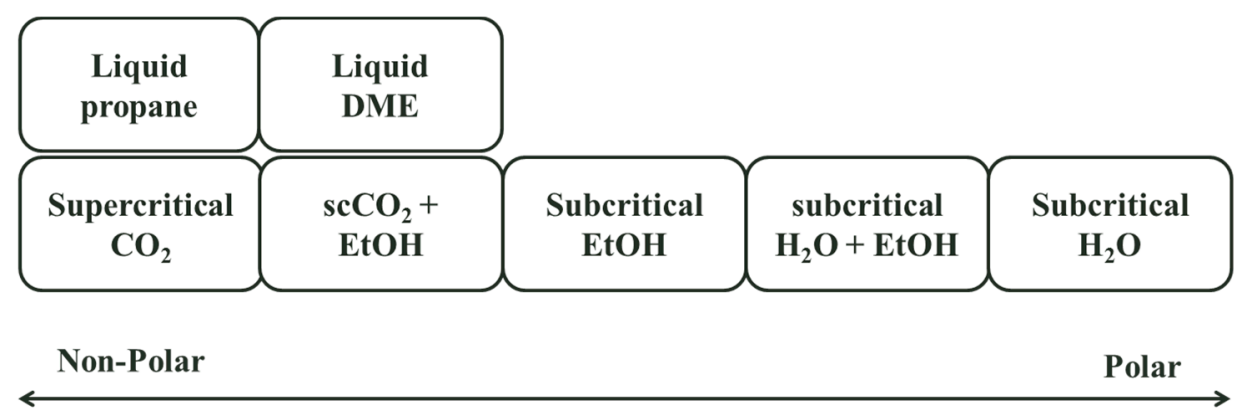

Figure 3. Sub- and supercritical mobile phases polarity. 
Finally, it would be beneficial to commercial development in the area of SFC to promote this technique at University and Doctorate level. SFC researchers have complained recently that there are no new or early stage researchers available to replace them or fill vacancies in certain countries.

Conflicts of Interest: The authors declare no conflict of interest.

\section{References}

1. Gagliardi, N. Consumers Want Healthy Foods-And Will Pay More for Them. Available online: https:/ / www.forbes.com/sites/nancygagliardi/2015/02/18/consumers-want-healthy-foods-andwill-pay-more-for-them/\#6571812875c5 (accessed on 27 July 2018).

2. Research, A.M. Omega-3 Market to Reach \$6,955 Million, Globally. 2022. Available online: https://www. alliedmarketresearch.com/press-release/omega-3-market.html (accessed on 27 July 2018).

3. Markets, M.A. Lecithin Market Worth 1.11 Billion Usd by 2020. Available online: https://www. marketsandmarkets.com/PressReleases/lecithin-phospholipids.asp (accessed on 27 July 2018).

4. Herrero, M.; Ibañez, E. Green extraction processes, biorefineries and sustainability: Recovery of high added-value products from natural sources. J. Supercrit. Fluids 2017, 134, 252-259. [CrossRef]

5. Iannuzzi, A. Greener Products: The Making and Marketing of Sustainable Brands; CRC Press: Boca Raton, FL, USA, 2011; p. 222.

6. Taylor, L.T. Supercritical fluid chromatography. Anal. Chem. 2010, 82, 4925-4935. [CrossRef] [PubMed]

7. Lesellier, E.; West, C. Description and comparison of chromatographic tests and chemometric methods for packed column classification. J. Chromatogr. A 2007, 1158, 329-360. [CrossRef] [PubMed]

8. West, C.; Lesellier, E. Characterisation of stationary phases in subcritical fluid chromatography with the solvation parameter model iv. Aromatic stationary phases. J. Chromatogr. A 2006, 1115, 233-245. [CrossRef] [PubMed]

9. West, C.; Lesellier, E. Characterisation of stationary phases in subcritical fluid chromatography by the solvation parameter model: Ii. Comparison tools. J. Chromatogr. A 2006, 1110, 191-199. [CrossRef] [PubMed]

10. West, C.; Lesellier, E. Characterisation of stationary phases in subcritical fluid chromatography with the solvation parameter model: Iii. Polar stationary phases. J. Chromatogr. A 2006, 1110, 200-213. [CrossRef] [PubMed]

11. West, C.; Lesellier, E. Characterization of stationary phases in subcritical fluid chromatography by the solvation parameter model: I. Alkylsiloxane-bonded stationary phases. J. Chromatogr. A 2006, 1110, 181-190. [CrossRef] [PubMed]

12. West, C.; Lesellier, E. Characterisation of stationary phases in supercritical fluid chromatography with the solvation parameter model. V. Elaboration of a reduced set of test solutes for rapid evaluation. J. Chromatogr. A 2007, 1169, 205-219. [CrossRef] [PubMed]

13. West, C.; Lesellier, E. A unified classification of stationary phases for packed column supercritical fluid chromatography. J. Chromatogr. A 2008, 1191, 21-39. [CrossRef] [PubMed]

14. West, C.; Lesellier, E. Comments on the paper "characterization of stationary phases by a linear solvation energy relationship utilizing supercritical fluid chromatography" by C.R. Mitchell, N.J. Benz, S. Zhang. J. Sep. Sci. 2011, 34, 1917-1924. [CrossRef] [PubMed]

15. Yamada, T.; Taguchi, K.; Bamba, T. Chapter 14-separation of lipids a2-Poole, colin f. In Supercritical Fluid Chromatography; Elsevier: New York, NY, USA, 2017; pp. 419-438.

16. Fornari, T.; Stateva, R.P. High Pressure Fluid Technology for Green Food Processing; Springer International Publishing: Basel, Switzerland, 2014.

17. Montanes, F.; Catchpole, O.; Tallon, S.; Rose, P.; Moreno-Rueda, T. Advances in analytical and preparative supercritical fluid chromatography. Food and nutraceutical applications. In High Pressure Fluid Technology for Green Food Processing; Tiziana, F., Stateva, R.P., Eds.; Springer International Publishing: Basel, Switzerland, 2015.

18. Poole, C. Supercritical Fluid Chromatography; Elsevier: New York, NY, USA, 2017; pp. i-iii.

19. Hermansson, M.; Uphoff, A.; Käkelä, R.; Somerharju, P. Automated quantitative analysis of complex lipidomes by liquid chromatography/mass spectrometry. Anal. Chem. 2005, 77, 2166-2175. [CrossRef] [PubMed] 
20. Doughman, S.D.; Krupanidhi, S.; Sanjeevi, C.B. Omega-3 fatty acids for nutrition and medicine: Considering microalgae oil as a vegetarian source of EPA and DHA. Curr. Diabetes Rev. 2007, 3, 198-203. [CrossRef] [PubMed]

21. Kim, S.H.; Kim, S.Y.; Kim, J.B.; Roh, K.H.; Kim, Y.M.; Park, J.S. Biosynthesis of polyunsaturated fatty acids: Metabolic engineering in plants. J. Appl. Biol. Chem. 2009, 52, 93-102. [CrossRef]

22. Joanneke, S. Algae: Our Original Omega-3 Source. Available online: https://www.wur.nl/upload_mm/ d/7/4/b749c4e6-c5bf-47f3-9a5e-3308a136c272_Flyer_Algen\%20onze\%20oorspronkelijke\%20omega-3\% 20bron\%2010\%20Mei\%202017\%20ENG.\%20Losse\%20pagina\%27s\%20Definitief\%20Press.pdf (accessed on 27 July 2018).

23. Catchpole, O.; Moreno, T.; Montañes, F.; Tallon, S. Perspectives on processing of high value lipids using supercritical fluids. J. Supercrit. Fluids 2018, 134, 260-268. [CrossRef]

24. Higashidate, S.; Yamauchi, Y.; Saito, M. Enrichment of eicosapentaenoic acid and docosahexaenoic acid esters from esterified fish oil by programmed extraction-elution with supercritical carbon dioxide. J. Chromatogr. A 1990, 515, 295-303. [CrossRef]

25. Perrut, M.; Nicoud, R.M.; Breivik, H. Processes for Chromatographic Fractionation of Fatty Acids and Their Derivatives. U.S. Patent 5719302, 17 February 1998.

26. Alkio, M.; Gonzalez, C.; Jäntti, M.; Aaltonen, O. Purification of polyunsaturated fatty acid esters from tuna oil with supercritical fluid chromatography. J. Am. Oil Chem. Soc. 2000, 77, 315-321. [CrossRef]

27. Nilsson, W.B.; Gauglitz, E.J., Jr.; Hudson, J.K.; Stout, V.F.; Spinelli, J. Fractionation of menhaden oil ethyl esters using supercritical fluid $\mathrm{CO}_{2}$. J. Am. Oil Chem. Soc. 1988, 65, 109-117. [CrossRef]

28. Snoey-Elich, H. Novel Method for Preparing Eicosapentaenoic Acid. Patent ES2159257 A1, 2001.

29. Pettinello, G.; Bertucco, A.; Pallado, P.; Stassi, A. Production of epa enriched mixtures by supercritical fluid chromatography: From the laboratory scale to the pilot plant. J. Supercrit. Fluids 2000, 19, 51-60. [CrossRef]

30. Lembke, P. Process-scale sfc: A feasibility study. In Proceedings of the 7th International Symposium on Supercritical Fluid Chromatography and Extraction, Indianapolis, IN, USA, 31 March-4 April 1996.

31. Montañés, F.; Catchpole, O.J.; Tallon, S.; Mitchell, K.; Lagutin, K. Semi-preparative supercritical chromatography scale plant for polyunsaturated fatty acids purification. J. Supercrit. Fluids 2013, 79, 46-54. [CrossRef]

32. Montañés, F.; Tallon, S.; Catchpole, O. Isolation of non-methylene interrupted or acetylenic fatty acids from seed oils using semi-preparative supercritical chromatography. J. Am. Oil Chem. Soc. 2017, 94, 981-991. [CrossRef]

33. Chien, T.C.; Lo, S.F.; Ho, C.L. Chemical composition and anti-inflammatory activity of Chamaecyparis obtusa f. Formosana wood essential oil from taiwan. Nat. Prod. Commun. 2014, 9, 723-726. [PubMed]

34. Morishige, J.I.; Amano, N.; Hirano, K.; Nishio, H.; Tanaka, T.; Satouchi, K. Inhibitory effect of juniperonic acid $(\delta-5 c, 11 c, 14 c, 17 c-20: 4, \omega-3)$ on bombesin-induced proliferation of swiss 3t3 cells. Biol. Pharm. Bull. 2008, 31, 1786-1789. [CrossRef] [PubMed]

35. Asset, G.; Baugé, E.; Wolff, R.L.; Fruchart, J.C.; Dallongeville, J. Pinus pinaster oil affects lipoprotein metabolism in apolipoprotein e-deficient mice. J. Nutr. 1999, 129, 1972-1978. [CrossRef] [PubMed]

36. Ikeda, I.; Imasato, Y.; Sasaki, E.; Nakayama, M.; Nagao, H.; Takeo, T.; Yayabe, F.; Sugano, M. Tea catechins decrease micellar solubility and intestinal absorption of cholesterol in rats. Biochim. Biophys. Acta (BBA)/Lipids Lipid Metab. 1992, 1127, 141-146. [CrossRef]

37. Nishiyama, N.; Chu, P.J.; Saito, H. Beneficial effects of biota, a traditional chinese herbal medicine, on learning impairment induced by basal forebrain-lesion in mice. Biol. Pharm. Bull. 1995, 18, 1513-1517. [CrossRef] [PubMed]

38. Nishiyama, N.; Wang, Y.L.; Saito, H. Beneficial effects of s-113m, a novel herbal prescription, on learning impairment model in mice. Biol. Pharm. Bull. 1995, 18, 1498-1503. [CrossRef] [PubMed]

39. Nishiyama, N.; Wang, Y.-L.; Saito, H. Effects of biota (bai-zi-ren), a traditional chinese medicine, on learning performances in mice. Jpn. J. Pharmacogn. 1992, 46, 62-70.

40. Chavali, A.K.; Gianchandani, E.P.; Tung, K.S.; Lawrence, M.B.; Peirce, S.M.; Papin, J.A. Characterizing emergent properties of immunological systems with multi-cellular rule-based computational modeling. Trends Immunol. 2008, 29, 589-599. [CrossRef] [PubMed]

41. Sugano, M.; Koga, T.; Yamato, T.; Nonaka, M.; Gu, J.Y. Trans fatty acids: Effects on eicosanoid production. World Rev. Nutr. Diet. 1994, 75, 179-182. [PubMed] 
42. Taylor, S.L.; King, J.W. Preparative-scale supercritical fluid extraction/supercritical fluid chromatography of corn bran. J. Am. Oil Chem. Soc. 2002, 79, 1133-1136. [CrossRef]

43. Osseo, L.S.; Caputo, G.; Gracia, I.; Reverchon, E. Continuous fractionation of used frying oil by supercritical $\mathrm{CO}_{2}$. J. Am. Oil Chem. Soc. 2004, 81, 879-885. [CrossRef]

44. Choo, Y.M.; Ma, A.N.; Yahaya, H.; Yamauchi, Y.; Bounoshita, M.; Saito, M. Separation of crude palm oil components by semipreparative supercritical fluid chromatography. J. Am. Oil Chem. Soc. 1996, 73, 523-525. [CrossRef]

45. Restuccia, D.; Spizzirri, U.G.; Puoci, F.; Cirillo, G.; Vinci, G.; Picci, N. Determination of phospholipids in food samples. Food Rev. Int. 2012, 28, 1-46. [CrossRef]

46. Wang, X.J.; Zhao, S.Q.; Wang, R.A. Analysis of soybean lecithin by supercritical fluid chromatography. Se pu = Chin. J. Chromatogr. 2001, 19, 344-346.

47. Yamada, T.; Bamba, T. Lipid profiling by supercritical fluid chromatography/mass spectrometry. In Neuromethods; Springer: Berlin, Germany, 2017; Volume 125, pp. 109-131.

48. Lee, J.W.; Nishiumi, S.; Yoshida, M.; Fukusaki, E.; Bamba, T. Simultaneous profiling of polar lipids by supercritical fluid chromatography/tandem mass spectrometry with methylation. J. Chromatogr. A 2013, 1279, 98-107. [CrossRef] [PubMed]

49. Taylor, S.L.; King, J.W.; Montanari, L.; Fantozzi, P.; Blanco, M.A. Enrichment and fractionation of phospholipid concentrates by supercritical fluid extraction and chromatography. Ital. J. Food Sci. 2000, 12, 65-76.

50. Uchikata, T.; Matsubara, A.; Fukusaki, E.; Bamba, T. High-throughput phospholipid profiling system based on supercritical fluid extraction-supercritical fluid chromatography/mass spectrometry for dried plasma spot analysis. J. Chromatogr. A 2012, 1250, 69-75. [CrossRef] [PubMed]

51. King, J.W. (University of Arkansas, Fayetteville, NC, USA). Theory and Applications of Critical Fluids in Engineering, Unpublished work, 2010.

52. Sanz, M.L.; Martínez-Castro, I. Recent developments in sample preparation for chromatographic analysis of carbohydrates. J. Chromatogr. A 2007, 1153, 74-89. [CrossRef] [PubMed]

53. Guthrie, E.J.; Schwartz, H.E. Integral pressure restrictor for capillary sfc. J. Chromatogr. Sci. 1986, 24, $236-241$. [CrossRef]

54. Lafosse, M.; Herbreteau, B.; Morin-Allory, L. Supercritical fluid chromatography of carbohydrates. J. Chromatogr. A 1996, 720, 61-73. [CrossRef]

55. Montañés, F.; Corzo, N.; Olano, A.; Reglero, G.; Ibáñez, E.; Fornari, T. Selective fractionation of carbohydrate complex mixtures by supercritical extraction with $\mathrm{CO}_{2}$ and different co-solvents. J. Supercrit. Fluids 2008, 45, 189-194. [CrossRef]

56. Montañés, F.; Fornari, T.; Martín-Álvarez, P.J.; Corzo, N.; Olano, A.; Ibáñez, E. Selective recovery of tagatose from mixtures with galactose by direct extraction with supercritical $\mathrm{CO}_{2}$ and different cosolvents. J. Agric. Food Chem. 2006, 54, 8340-8345. [CrossRef] [PubMed]

57. Montañés, F.; Fornari, T.; Martín-Álvarez, P.J.; Montilla, A.; Corzo, N.; Olano, A.; Ibáñez, E. Selective fractionation of disaccharide mixtures by supercritical $\mathrm{CO}_{2}$ with ethanol as co-solvent. J. Supercrit. Fluids 2007, 41, 61-67. [CrossRef]

58. Montañés, F.; Fornari, T.; Olano, A.; Ibáñez, E. Supercritical fluid purification of complex carbohydrate mixtures produced by enzimatic transglycosilation and isomerized with complexating reagents. J. Supercrit. Fluids 2010, 53, 25-33. [CrossRef]

59. Montañés, F.; Fornari, T.; Stateva, R.P.; Olano, A.; Ibáñez, E. Solubility of carbohydrates in supercritical carbon dioxide with (ethanol + water) cosolvent. J. Supercrit. Fluids 2009, 49, 16-22. [CrossRef]

60. Salvador, A.; Herbreteau, B.; Lafosse, M.; Dreux, M. Subcritical fluid chromatography of monosaccharides and polyols using silica and trimethylsilyl columns. J. Chromatogr. A 1997, 785, 195-204. [CrossRef]

61. Lefler, J.L.; Chen, R. A feasibility study of using supercritical fluid chromatography (sfc)-uv-elsd for food and beverage analyses. LC GC N. Am. 2008, 26, 42-43.

62. Montañés, F.; Rose, P.; Tallon, S.; Shirazi, R. Separation of derivatized glucoside anomers using supercritical fluid chromatography. J. Chromatogr. A 2015, 1418, 218-223. [CrossRef] [PubMed]

63. Saito, M.; Yamauchi, Y. Isolation of tocopherols from wheat germ oil by recycle semi-preparative supercritical fluid chromatography. J. Chromatogr. A 1990, 505, 257-271. [CrossRef] 
64. Johannsen, M.; Brunner, G. Supercritical fluid chromatography as successful separation tool in chemical and pharmaceutical industry. In Proceedings of the 9th Meeting on Supercritical Fluids, Trieste, Italy, 13-16 June 2004.

65. Peper, S.; Crammerer, S.; Johannsen, M.; Brunner, G. Supercritical fluid chromatography: Process optimization of the separation of tocopherol homologues. In Proceedings of the International Symposium on Supercritical Fluids, Versailles, France, 28-30 April 2003.

66. Ramírez, P.; García-Risco, M.R.; Santoyo, S.; Señoráns, F.J; Ibáñez, E.; Reglero, G. Isolation of functional ingredients from rosemary by preparative-supercritical fluid chromatography (prep-sfc). J. Pharm. Biomed. Anal. 2006, 41, 1606-1613. [CrossRef] [PubMed]

67. Ramírez, P.; Santoyo, S.; García-Risco, M.R.; Señoráns, F.J.; Ibáñez, E.; Reglero, G. Use of specially designed columns for antioxidants and antimicrobials enrichment by preparative supercritical fluid chromatography. J. Chromatogr. A 2007, 1143, 234-242. [CrossRef] [PubMed]

68. Coleman, W.M.; Dube, M.F.; Ashraf-Khorassani, M.; Taylor, L.T. Isomeric enhancement of davanone from natural davana oil aided by supercritical carbon dioxide. J. Agric. Food Chem. 2007, 55, 3037-3043. [CrossRef] [PubMed]

69. Li, S.; Lambros, T.; Wang, Z.; Goodnow, R.; Ho, C.T. Efficient and scalable method in isolation of polymethoxyflavones from orange peel extract by supercritical fluid chromatography. J. Chromatogr. $B$ 2007, 846, 291-297. [CrossRef] [PubMed]

70. García-Risco, M.R.; Vicente, G.; Reglero, G.; Fornari, T. Fractionation of thyme (Thymus vulgaris L.) by supercritical fluid extraction and chromatography. J. Supercrit. Fluids 2011, 55, 949-954. [CrossRef]

71. Perrotin-Brunel, H.; Van Roosmalen, M.J.E.; Kroon, M.C.; Van Spronsen, J.; Witkamp, G.J.; Peters, C.J. Solubility of cannabinol in supercritical carbon dioxide. J. Chem. Eng. Data 2010, 55, 3704-3707. [CrossRef]

(C) 2018 by the authors. Licensee MDPI, Basel, Switzerland. This article is an open access article distributed under the terms and conditions of the Creative Commons Attribution (CC BY) license (http:/ / creativecommons.org/licenses/by/4.0/). 